\title{
Long-term outcomes after definitive repair for tetralogy of Fallot with preservation of the pulmonary valve annulus
}

\author{
Takaya Hoashi, MD, PhD, ${ }^{\mathrm{a}}$ Koji Kagisaki, MD, ${ }^{\mathrm{a}}$ Yin Meng, MD, ${ }^{\mathrm{a}}$ Heima Sakaguchi, MD, \\ Kenichi Kurosaki, MD, ${ }^{\mathrm{b}}$ Isao Shiraishi, MD, PhD, ${ }^{\mathrm{b}}$ Toshikatsu Yagihara, MD, ${ }^{\mathrm{a}}$ and \\ Hajime Ichikawa, MD, $\mathrm{PhD}^{\mathrm{a}}$
}

Objectives: The aim of our study was to evaluate the long-term outcomes after definitive repair of tetralogy of Fallot with preservation of the pulmonary valve (PV) annulus.

\begin{abstract}
Methods: From 1989 to 2000, 84 of 222 patients (37.8\%) with tetralogy of Fallot and PV stenosis underwent definitive repair with preservation of the PV annulus without right ventriculotomy. PV commissurotomy was concomitantly performed in 74 patients $(88.1 \%)$. The PV was bicuspid in 56 patients $(66.7 \%)$; the mean $\mathrm{Z}$ value was $-1.2 \pm 1.5$ (range, -4.9 to 2.4 ). The mean follow-up period was $15.8 \pm 5.7$ years (maximum, 22.8), and follow-up data were complete for 75 patients $(89.3 \%)$.
\end{abstract}

\begin{abstract}
Results: The actuarial survival and freedom from reoperation rates at 20 years was $98.6 \%$ and $95.8 \%$. The freedom from ventricular arrhythmia at 5, 10, 15, and 20 years was $98.7 \%, 89.6 \%, 74.1 \%$, and $58.0 \%$, respectively. All detected ventricular arrhythmias were isolated monofocal premature ventricular contractions. Freedom from moderate or greater pulmonary regurgitation at 5, 10, 15 and 20 years was $50.4 \%, 44.9 \%, 38.4 \%$, and $35.7 \%$, respectively. A bicuspid PV (hazard ratio, 2.910; 95\% confidence interval, 1.404-6.204, $P=.004$ ) and a $Z$-value of less than -2 (hazard ratio, $1.948 ; 95 \%$ confidence interval, $0.915-5.857 ; P=.034$ ) were the risk factors for developing moderate or greater pulmonary regurgitation.
\end{abstract}

Conclusions: The long-term outcomes after definitive repair of tetralogy of Fallot with preservation of the PV annulus were excellent. Although isolated, monofocal premature ventricular contractions were frequently observed, fatal ventricular arrhythmia was not. The indication should not only be decided by the PV annulus size, but also by the valvular morphology to maintain long-term PV competency. (J Thorac Cardiovasc Surg 2014;148:802-9)

Once extended long right ventriculotomy could be avoided at intracardiac repair, the life prognosis after tetralogy of Fallot (TOF) repair improved steadily, and many patients have survived to adulthood. ${ }^{1,2}$ Recently, the focus of surgical treatment has been to maintain right ventricular (RV) function for the patient's entire lifespan; thus, how to treat the RV outflow tract (RVOT) at intracardiac repair and how to identify the optimal timing of reoperation have become matters of concern.

Preservation of the pulmonary valve (PV) annulus without right ventriculotomy aims to maintain $\mathrm{PV}$ competency, which is expected to preserve late RV

\footnotetext{
From the Department of Pediatric Cardiovascular Surgery, ${ }^{\mathrm{a}}$ and Department of Pediatric Cardiology, ${ }^{\text {b }}$ National Cerebral and Cardiovascular Center, Suita, Osaka, Japan.

Disclosures: Authors have nothing to disclose with regard to commercial support.

Read at the 94th Annual Meeting of The American Association for Thoracic Surgery, Toronto, Ontario, Canada, April 26-30, 2014.

Received for publication April 9, 2014; revisions received May 31, 2014; accepted for publication June 4, 2014; available ahead of print July 1, 2014.

Address for reprints: Takaya Hoashi, MD, PhD, Division of Pediatric Cardiovascular Surgery, National Cerebral and Cardiovascular Center, 5-7-1, Fujishiro-dai, Suita, Osaka 565-8565, Japan (E-mail: thoashi@surg1.med.osaka-u.ac.jp).

$0022-5223 / \$ 36.00$

Copyright (c) 2014 by The American Association for Thoracic Surgery

http://dx.doi.org/10.1016/j.jtcvs.2014.06.008
}

function. Although several institutions have demonstrated the surgery's positive immediate outcomes, ${ }^{3-10}$ the longterm result has remained unclear. We reviewed our institutional long-term outcomes after repair of TOF with preservation of the PV annulus, focusing on late PV competency and the occurrence of ventricular arrhythmia.

\section{METHODS \\ Patients}

The National Cerebral and Cardiovascular Center institutional review board approved the present retrospective study and waived the need for patient consent. From 1977 to 2011, 610 patients had undergone repair of TOF and pulmonary stenosis at our center. Of those, the PV annulus was preserved in 191 patients $<18$ years old (Figure 1). We excluded 88 patients who had undergone surgery before 1989, because transverse right ventriculotomy had been performed during that period even if the PV annulus was preserved, and 19 patients after 2000 because of the short follow-up period. Thus, 84 patients were selected as the study cohort. The mean age and weight at surgery was $1.9 \pm 1.4$ years (range, 0.3-7.7) and $9.3 \pm 2.7 \mathrm{~kg}$ (range, 4.8-20.5), respectively. Eleven patients underwent staged repair $(13.1 \%$; Table 1$)$. The preoperative mean left ventricular (LV) end-diastolic volume was $118.9 \% \pm 39.5 \%$ of normal (range 61\%-280\%). Regarding PV morphology, 66.7\% patients had a bicuspid PV. The mean PV diameter was $10.5 \pm 2.3 \mathrm{~mm}$ (range, 6.4-16.3), which was equivalent to $93.9 \%$ of the normal size (range $54.9-156.5 \mathrm{~mm}$ ). The mean $Z$ value was $-1.3 \pm 1.5$ (range -4.9 to 2.4 ), and 23 patients $(29.1 \%)$ had a $\mathrm{Z}$ value of less than -2 . 


$$
\begin{aligned}
& \text { Abbreviations and Acronyms } \\
& \begin{aligned}
\mathrm{HR} & =\text { hazard ratio } \\
\mathrm{PR} & =\text { pulmonary regurgitation } \\
\mathrm{PV} & =\text { pulmonary valve } \\
\mathrm{RV} & =\text { right ventricular } \\
\mathrm{RVOT} & =\mathrm{RV} \text { outflow tract } \\
\mathrm{TOF} & =\text { tetralogy of Fallot }
\end{aligned}
\end{aligned}
$$

Except for 1 operation approached through a right atriotomy, all operations were approached by way of right atriotomy and pulmonary arteriotomy, without right ventriculotomy. The ventricular septal defect was closed through the tricuspid valve. The RVOT muscle bundles were divided through the tricuspid valve, and the fibrous endocardium surrounding the PV was resected. The hypertrophied parietal bands, free wall, or, sometimes, the conus septum was undermined through the PV until the subvalvular apparatus of the tricuspid valve could be clearly observed. PV commissurotomy was concomitantly performed in 74 patients $(88.1 \%)$. During the operation, the PV diameter was measured using Hegar dilators, and the size was recorded as the largest dilator that could fit without being forced. The mean $\mathrm{Z}$ value of the PV diameter after repair was $-0.4 \pm 0.7$ (range, -2.6 to 1.7 ). If necessary, the branch pulmonary stenosis was repaired using an appropriate enlargement patch. At the end of the procedure, the mean RV to LV pressure ratio was $0.56 \pm 0.15$ (range, 0.22-0.92).

A trend was seen toward the targeted age at operation and an indication for the preservation of the PV annulus method (Figure 2). In the early study period, more than one third of the patients were $>2$ years old at surgery. In addition, some of the patients were $<6$ months old at surgery. However, the operative age was almost limited to 6 months to 2 years in the late period (Figure 2, A). The indication for the preservation of the PV annulus had gradually increased during the early study period; thus, a small PV annulus with a $\mathrm{Z}$ value of less than -2 was frequently considered an indication (Figure 2, B). However, such a trend was not observed in the late period, in which the transannular patch method had been selected for more than two thirds of the patients (Figure 2, C).

\section{Study Method}

The present study was a retrospective, nonrandomized, singleinstitutional study. From the operative records, echocardiography and cardiac catheterization reports, and outpatient clinical records, the evaluated valuables were as follows: (1) overall outcomes (ie, mortality, freedom from reoperation rate, freedom from ventricular arrhythmia rate); (2) freedom from moderate or greater pulmonary regurgitation (PR) rate and risk factor analysis using the Cox proportional hazards model; and (3) a current evaluation of the survivors (ie, echocardiography, chest radiograph, New York Heart Association functional status, medications used, serum atrial and brain natriuretic peptide levels).

The 12-lead electrocardiographic data were routinely recorded at the annual outpatient clinic follow-up examination. Formal 24-hour Holter electrocardiographic data were recorded to examine the frequency and multiform of any detected arrhythmia. A 24-hour Holter electrocardiogram was also conducted for patients with palpitation if arrhythmia had not been detected on the 12-lead electrocardiogram.

RV dilatation was evaluated using 2-dimensional echocardiography. ${ }^{11}$ From the short-axis views at the LV basal region, RV dilatation was quantitatively classified as mild if the RV diastolic diameter ranged from one third to two thirds of the LV diastolic dimension, moderate if it ranged from two thirds to equal amounts, and severe if it was more than equal. Cardiac magnetic resonance imaging was performed if the degree of RV dilatation was considered severe on the 2-dimensional echocardiogram. Reoperation was indicated when the RV end-diastolic volume index was
$>200 \mathrm{~mL} / \mathrm{m}^{2}$. The severity of PR was estimated by Doppler color flow mapping and was graded as none to mild, moderate, and severe. Reoperation for recurrent RVOT obstruction was indicated if the RV to LV pressure ratio had increased to $>0.8$. The overall mortality, freedom from reoperation, freedom from ventricular arrhythmia, and the prevalence of moderate or greater PR were estimated using the Kaplan-Meier method. The data were analyzed using PASW Statistics 18 software (SPSS Inc, Chicago, Ill).

\section{RESULTS \\ Overall Outcomes}

The mean follow-up duration was $15.8 \pm 5.7$ years (range, 6.4-22.8), and the follow-up data were complete for 75 of the 84 patients $(89.3 \%)$. The actuarial survival rate at 20 years was $98.6 \%$ (Figure 3, A). During the follow-up period, 1 patient died 10 years after the operation of an unknown etiology. At this patient's examination at our outpatient clinic, 1 month before the patient's sudden death, no arrhythmia had been recorded on the electrocardiogram, and no palpitation had been noted. The freedom from reoperation rate at 20 years was $95.8 \%$ (Figure $3, B$ ). Three patients required reoperation during the follow-up period, 1 for recurrent left pulmonary branch stenosis, 1 for both pulmonary and tricuspid regurgitation and cardiac resynchronization therapy system implantation, and 1 for recurrent RVOT obstruction. The freedom from ventricular arrhythmia rate at $5,10,15$, and 20 years was $98.7 \%$, $89.6 \%, 74.1 \%$, and $58.0 \%$, respectively (Figure 3, C). All cases of ventricular arrhythmia detected were isolated monofocal premature ventricular contraction; fatal ventricular arrhythmia was not observed.

\section{Preserved Pulmonary Valve Competency}

The freedom from moderate or greater PR rate at 5, 10, 15 , and 20 years was $50.4 \%, 44.9 \%, 38.4 \%$, and $35.7 \%$, respectively (Figure 3,D). A bicuspid PV (hazard ratio [HR], 2.910; 95\% confidence interval [CI], 1.404-6.204;

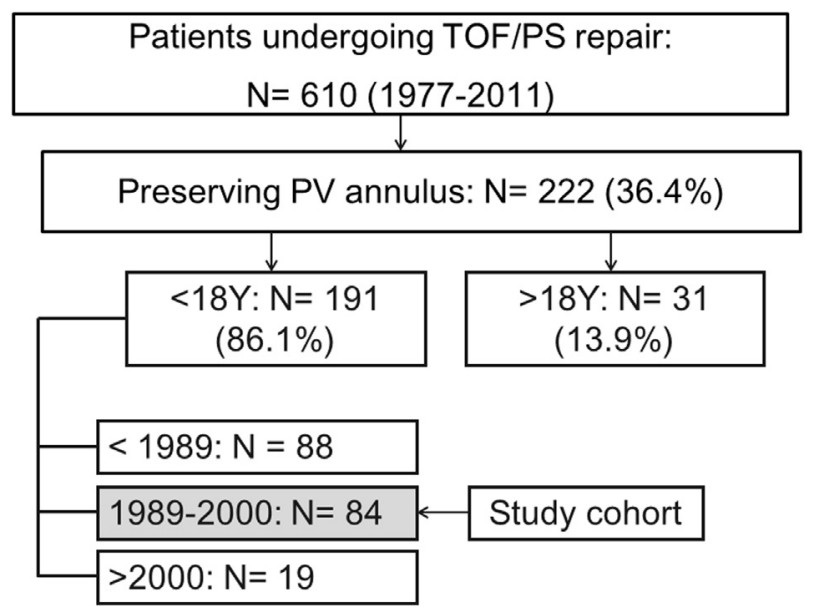

FIGURE 1. Flow chart showing selection of study cohort. TOF, Tetralogy of Fallot; $P S$, pulmonary stenosis; $P V$, pulmonary valve; $Y$, years old. 
TABLE 1. Patient characteristics

\begin{tabular}{|c|c|}
\hline Characteristic & Value \\
\hline Patients (n) & 84 \\
\hline \multicolumn{2}{|l|}{$\operatorname{Sex}(n)$} \\
\hline Male & 47 \\
\hline Female & 37 \\
\hline \multicolumn{2}{|l|}{ Age at surgery $(y)$} \\
\hline Mean \pm SD & $1.9 \pm 1.4$ \\
\hline Range & $0.3-7.7$ \\
\hline \multicolumn{2}{|l|}{ Body weight at surgery (kg) } \\
\hline Mean \pm SD & $9.3 \pm 2.7$ \\
\hline Range & $4.8-20.5$ \\
\hline Previous SP shunt (n) & $11(13.1)$ \\
\hline \multicolumn{2}{|l|}{ LVEDV ( $\%$ of normal) } \\
\hline Mean \pm SD & $118.9 \pm 39$. \\
\hline Range & $61-280$ \\
\hline \multicolumn{2}{|l|}{ LVEF $(\%)$} \\
\hline Mean $\pm \mathrm{SD}$ & $67.3 \pm 6.7$ \\
\hline Range & $52-83$ \\
\hline \multicolumn{2}{|c|}{ Associated chromosome anomaly (n) } \\
\hline Trisomy 21 & 6 \\
\hline 22q11.2 Microdeletion & 2 \\
\hline Other & 2 \\
\hline \multicolumn{2}{|l|}{ Pulmonary valve morphology (n) } \\
\hline Bicuspid & $56(66.7)$ \\
\hline Tricuspid & $27(32.1)$ \\
\hline Unknown & 1 \\
\hline \multicolumn{2}{|l|}{ Pulmonary annulus diameter } \\
\hline \multicolumn{2}{|l|}{$\mathrm{Mm}$} \\
\hline Mean $\pm \mathrm{SD}$ & $10.5 \pm 2.3$ \\
\hline Range & $6.4-16.3$ \\
\hline \multicolumn{2}{|l|}{$\%$ of Normal } \\
\hline Mean \pm SD & $93.9 \pm 19$. \\
\hline Range & $54.9-156.5$ \\
\hline \multicolumn{2}{|l|}{$Z$ value } \\
\hline Mean \pm SD & $-1.3 \pm 1.5$ \\
\hline Range & -4.9 to 2.4 \\
\hline $\mathrm{Z}$ value $<-2(\mathrm{n})$ & $23(27.7)$ \\
\hline \multicolumn{2}{|l|}{ Surgical approach (n) } \\
\hline Trans-PA and RA & $83(98.8)$ \\
\hline Trans-RA & $1(1.2)$ \\
\hline With right ventriculotomy & 0 \\
\hline \multicolumn{2}{|l|}{ Pulmonary valve plasty (n) } \\
\hline Commissurotomy & $74(88.1)$ \\
\hline Without commissurotomy & $10(11.9)$ \\
\hline \multicolumn{2}{|c|}{ Pulmonary annulus diameter after CPB ( $\mathrm{Z}$ value) } \\
\hline Mean \pm SD & $-0.4 \pm 0.7$ \\
\hline Range & -2.6 to 1.7 \\
\hline \multicolumn{2}{|l|}{$\mathrm{RV} / \mathrm{LV}$ pressure ratio after $\mathrm{CPB}$} \\
\hline Mean \pm SD & $0.56 \pm 0.1$ \\
\hline Range & $0.22-0.92$ \\
\hline $\mathrm{RV} / \mathrm{LV}$ pressure ratio $>0.7$ (n) & $10(12.5)$ \\
\hline
\end{tabular}

Data in parentheses are percentages. $S D$, Standard deviation; $S P$, systemic-topulmonary; $L V E D V$, left ventricular end-diastolic volume; $P A$, pulmonary artery; $R A$, right atrium; $R V$, right ventricular; $L V$, left ventricular; $C P B$, cardiopulmonary bypass; $L V E F$, left ventricular ejection fraction.

$P=.004)$ and $\mathrm{Z}$ value of less than $-2(\mathrm{HR}, 1.948 ; 95 \% \mathrm{CI}$, $0.915-5.857 ; P=.034)$ were risk factors for developing moderate or greater PR (Figure 4). Of these 2 factors, multivariate analysis detected only the bicuspid PV (HR, 3.581; $95 \% \mathrm{CI}, 1.481-8.661 ; P=.005)$ as the significant risk factor. Concomitant commissurotomy (HR, 2.315; 95\% CI, $0.915-5.857 ; P=.076$ ), body weight at surgery (HR, $0.911 ; 95 \%$ CI, $0.809-1.026$; $P=.124)$, and the PV Z value (HR, $0.888 ; 95 \%$ CI, 0.744-1.059; $P=.186$ ) were not risk factors.

\section{Current Evaluation of Survivors}

In the previous 2 years, 74 of the 83 survivors were admitted to our outpatient clinic and underwent a medical examination, echocardiography, chest radiography, and blood sampling (Table 2). The mean cardiothoracic ratio on the chest radiograph was $51.7 \% \pm 6.9 \%$ (range, $41.3 \%-73 \%)$. On echocardiography, 49 patients $(66.2 \%)$ had RV dilatation due to progressive PR. The mean pressure gradient across the RVOT was $14.9 \pm 8.6 \mathrm{~mm} \mathrm{Hg}$ (range, $3-28$ ), and the mean $\mathrm{Z}$ value of the $\mathrm{PV}-0.6 \pm 1.3$ (range, -3.0 to 1.7$)$.

The New York Heart Association functional status was class I in 70 patients and class II in 4 . Of these 74 patients, $71(95.9 \%)$ were free from medication. The mean serum atrial and brain natriuretic peptide level was $30.7 \pm 20.0$ $\mathrm{pg} / \mathrm{mL}$ (range, 9-98) and $23.5 \pm 17.2 \mathrm{pg} / \mathrm{mL}$ (range, 6.4-79.4).

\section{DISCUSSION}

This is the longest follow-up study concerning the repair of TOF with preservation of the PV annulus without right ventriculotomy. Our study has demonstrated excellent long-term outcomes in terms of the life prognosis and freedom from reoperation rate. During the mean followup period of 15.8 years, only 1 late mortality was observed, and the overall survival rate at 20 years was $98.6 \%$. Reoperation for recurrent RVOT obstruction was required in only 1 patient, and the freedom from reoperation rate at 20 years was $95.8 \%$. The incidence of isolated, monofocal premature ventricular contraction gradually increased; however, fatal ventricular tachyarrhythmia was not observed. More than one third of the patients maintained good PV competency for $>20$ years after surgery. A small pulmonary annulus and bicuspid PV were risk factors for early progression of moderate or greater PR. Although most of the patients were in good status and free from medication, two thirds of the patients had qualitatively dilated right ventricle owing to concomitant PR.

\section{Indication for Pulmonary Annulus Preservation Without Right Ventriculotomy}

An indication for the strategy of preserving the pulmonary annulus without right ventriculotomy has been well described. Although a $\mathrm{Z}$ value of less than -4 , a bicuspid $\mathrm{PV}$, and an $\mathrm{RV} / \mathrm{LV}$ pressure ratio of $>0.7$ have been thought 
(n)
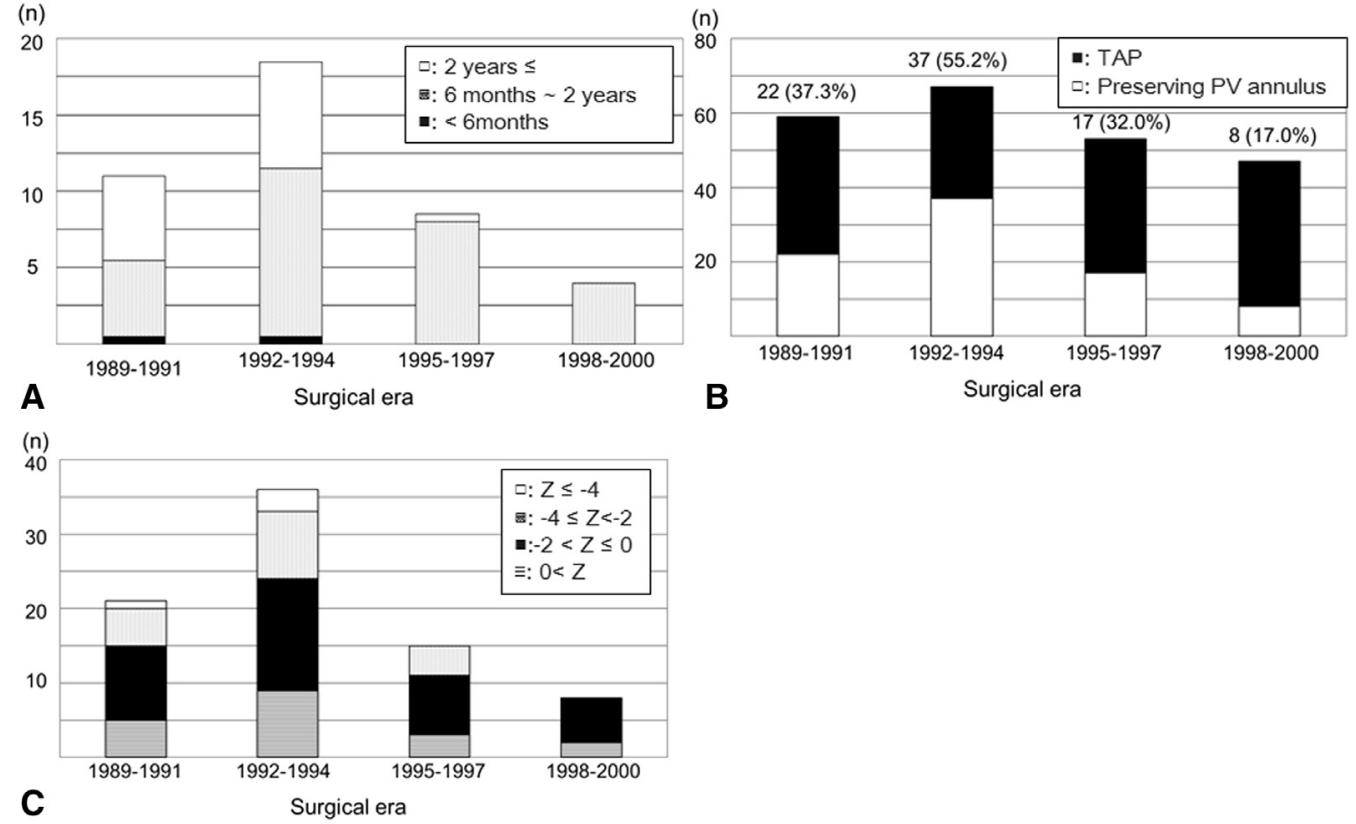

FIGURE 2. A, Trend for the targeted timing of intracardiac repair with preservation of the pulmonary valve $(P V)$ annulus. The open bars indicate the number of patients undergoing intracardiac repair at $\geq 2$ years old. The dotted bars indicate patients aged 6 months to 2 years. The closed bars indicate those aged $<6$ months. B, The number of patients who underwent intracardiac repair with preservation of PV annulus (open bars) or transannular patching $(T A P)$ with right ventriculotomy (closed bars). C, The PV annulus $\mathrm{Z}$ value of patients undergoing intracardiac repair with preservation of the PV annulus. Open bars indicate the number of patients with a $\mathrm{Z}$ value of less than -4 , dotted bars, number with a $\mathrm{Z}$ value of -4 to -2 , closed bars, number with a $Z$ value of -2 to 0 , and cross bars, number with a $\mathrm{Z}$ value $>0$.

to be risk factors for reoperation for recurrent RVOT obstruction, ${ }^{5}$ some reports, including small right ventriculotomy cases, have concluded that the PV could be preserved in most patients who were intended to do that. ${ }^{4,6,7}$ In the present study, although a bicuspid PV and Z value of less than -2 were detected as risk factors for early progression of moderate or greater PR, they were not risk factors for recurrent RVOT obstruction. In addition, neither the patients whose PV annulus diameter size was less than normal nor those whose RV/LV pressure ratio was $>0.7$ after weaning from cardiopulmonary bypass, developed recurrent RVOT obstruction. Of the patients in our cohort, $12.5 \%$ had an RV/LV pressure ratio of $>0.7$. Hypertrophy of the right ventricle gradually regressed after surgery and dynamic obstruction in the right ventricle diminished. Not only the division of a prominent obstructive parietal band, but also an aggressive undermining of the hypertrophied muscle bundles surrounding the RVOT and resection of the thickened fibrous endocardium contributed to preventing recurrent RVOT stenosis.

\section{Small PV Annulus}

Excessive commissurotomy to enlarge the significantly small PV annulus and subsequent infundibulectomy by way of a relatively small PV annulus without right ventriculotomy provided a good reoperation-free rate for recurrent RVOT obstruction; however, it adversely affected postoperative PV competency. PV leaflets that have been partially detached from the annulus at commissure and, sometimes, a PV annulus divided by extended commissurotomy beyond the media layer, and/or a subclinical, but aneurysmally dilated, RVOT can cause significant PR just after surgery, emerging after regression of RV restrictive physiology. Although the PV annulus $\mathrm{Z}$ value itself did not correlate with the development of moderate or greater PR because of its wide dispersion, a $Z$ value of -2 was detected as the cutoff value on the receiver operating characteristic curve and was a significant risk factor for the development of moderate or greater PR on univariate analysis. Multivariate analysis did not identify the $\mathrm{Z}$ value as a risk factor, because the results were strongly biased by the trend of the indication explained in Figure 2. Therefore, if all patients with a $Z$ value of less than -2 were anticipated to undergo surgery with preservation of the PV annulus, which must strongly relate to the adverse late PV function or frequency of reoperation on the RVOT.

\section{Bicuspid PV}

A bicuspid $\mathrm{PV}$ is a common anomalous form associated with TOF. In the present cohort study, more than two thirds of the patients had a bicuspid PV. Although the annulus diameter of the bicuspid PV ( $\mathrm{Z}=-1.46 \pm 1.6)$ was not significantly smaller than that of a tricuspid PV $(\mathrm{Z}=-0.76 \pm 1.3 ; P=.084)$, several properties could 
$98.6 \%$ at 20 years

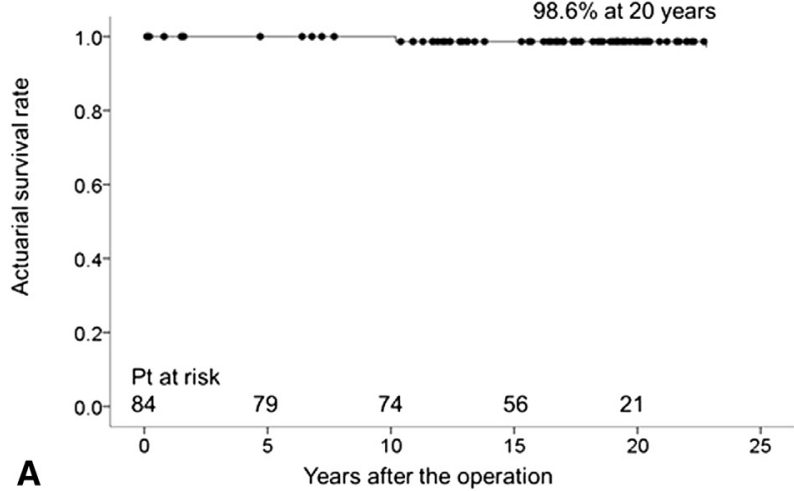

A

Years after the operation
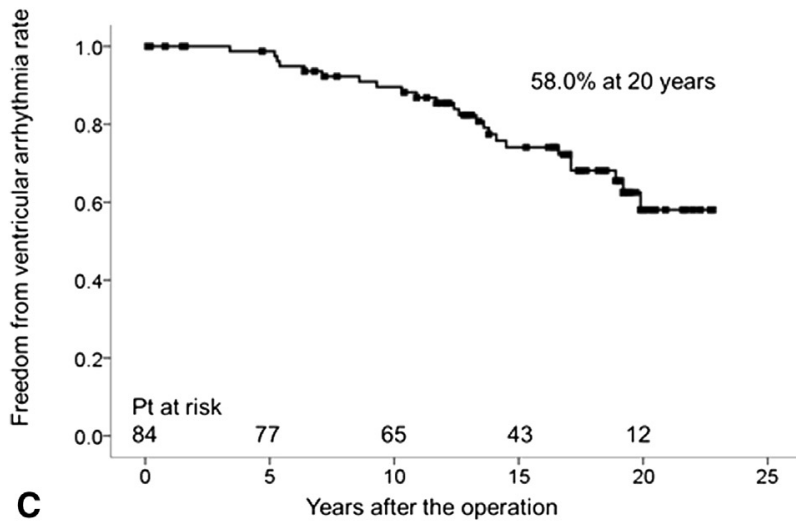
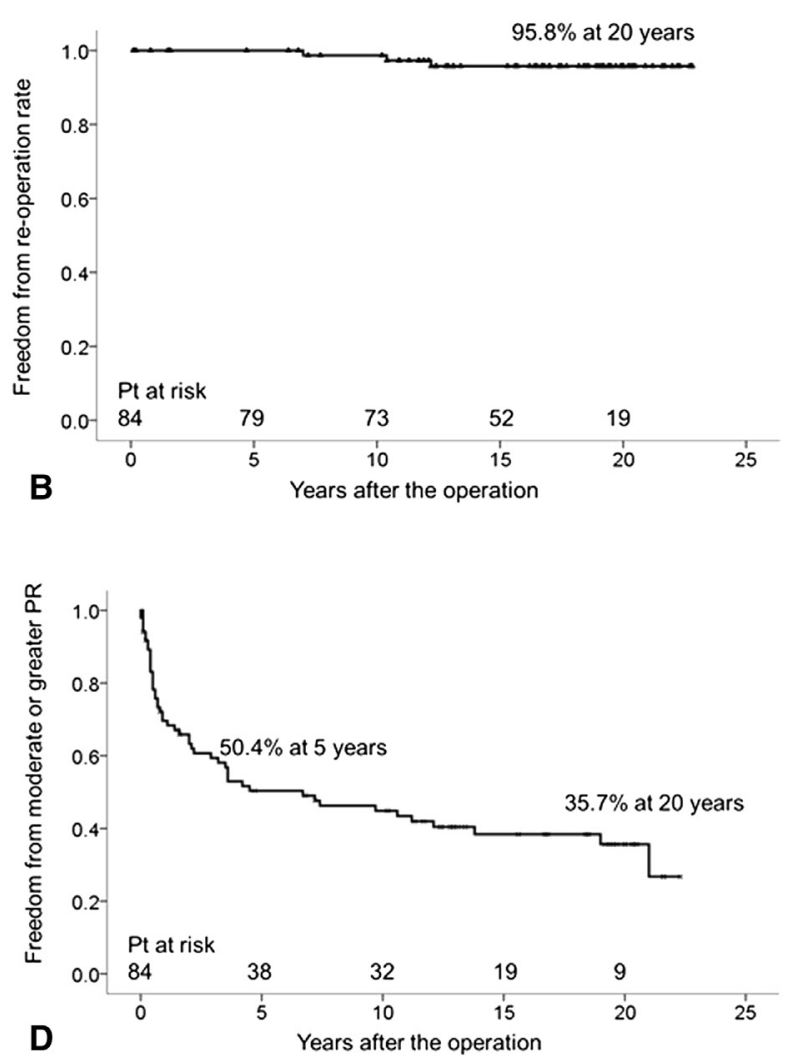

FIGURE 3. Kaplan-Meier curves of (A) survival rate, (B) freedom from reoperation rate, (C) freedom from ventricular arrhythmia rate, and (D) freedom from moderate or greater pulmonary regurgitation $(P R)$ in patients undergoing definitive repair with preservation of the pulmonary valve annulus without right ventriculotomy. $P t$, Patients.

negatively affect late PV competency. In contrast to a normal tricuspid PV with 3 commissures, widening of the PV orifice will be limited because the commissurotomy can only be accomplished in 2 directions on both commissures. ${ }^{5}$ Therefore, the previously mentioned excessive commissurotomy was required to maintain an effective orifice area, which impaired PV competency. Also, the leaflets of the bicuspid PV will be intrinsically thickened with myxomatous changes, which might be unsuitable for long-term use.

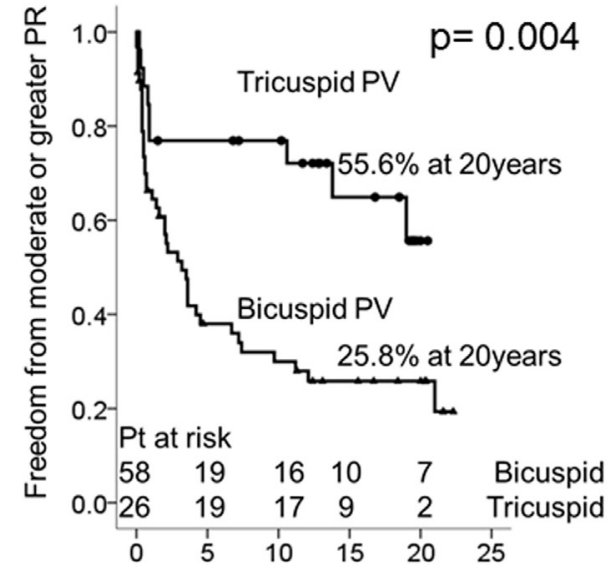

A Years after the operation

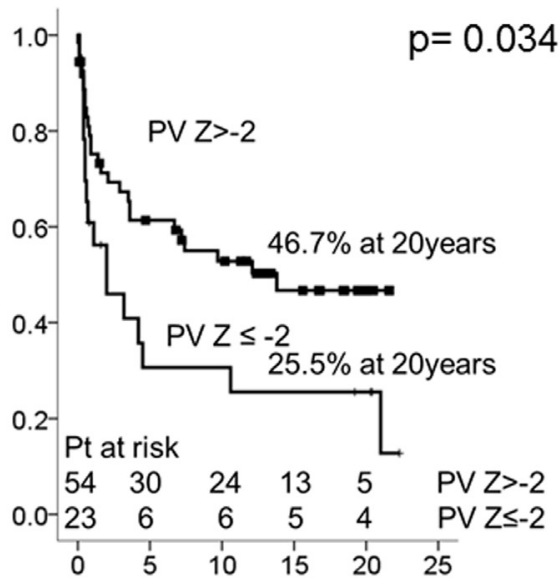

B Years after the operation

FIGURE 4. Kaplan-Meier curves of (A) freedom from moderate or greater pulmonary regurgitation $(P R)$ by pulmonary valve $(P V)$ morphology and (B) Z value. Pt, Patient. 
TABLE 2. Latest evaluation of survivors $(n=74)$

\begin{tabular}{|c|c|}
\hline Variable & Value \\
\hline Patients (n) & 74 \\
\hline Study period (after ICR $[y]$ ) & $17.0 \pm 3.5(9.1-22.8)$ \\
\hline \multicolumn{2}{|l|}{ Echocardiogram } \\
\hline RV dilatation & $49(66.2)$ \\
\hline Mild & $30(40.5)$ \\
\hline Moderate & $19(25.7)$ \\
\hline Severe & $0(0)$ \\
\hline PR moderate or greater & $49(66.2)$ \\
\hline TR moderate or greater & $9(12.2)$ \\
\hline RVOTPG (mm Hg) & $14.9 \pm 8.6(3-28)$ \\
\hline LVDd (\% of normal) & $92.6 \pm 9.4(46-108)$ \\
\hline LVEF $(\%)$ & $69.7 \pm 9.7(33-83)$ \\
\hline Pulmonary annulus diameter ( $\mathrm{Z}$ value) & $-0.6 \pm 1.3(-3.0$ to 1.7$)$ \\
\hline CTR $(\%)$ & $51.7 \pm 6.9(41.3-73)$ \\
\hline \multicolumn{2}{|l|}{ Status } \\
\hline \multicolumn{2}{|l|}{ NYHA (n) } \\
\hline I & 70 \\
\hline II & 4 \\
\hline \multicolumn{2}{|l|}{ Medication (n) } \\
\hline None & 71 \\
\hline Diuretics & 3 \\
\hline \multicolumn{2}{|l|}{ Biomarker of heart failure $(\mathrm{pg} / \mathrm{mL})$} \\
\hline $\operatorname{ANP}(n=31)$ & $30.7 \pm 20.0(9-98)$ \\
\hline $\operatorname{BNP}(n=39)$ & $23.5 \pm 17.2(6.4-79.4)$ \\
\hline \multicolumn{2}{|c|}{$\begin{array}{l}\text { Data presented as n, } \mathrm{n}(\%) \text {, or mean } \pm \mathrm{SD} \text { (range). ICR, Intracardiac repair; } R V \text {, right } \\
\text { ventricular; } P R \text {, pulmonary regurgitation; } T R \text {, tricuspid regurgitation; } R V O T P G \text {, } \\
\mathrm{RV} \text { outflow tract pressure gradient; } L V D d \text {, left ventricular end-diastolic diameter; } \\
L V E F \text {, left ventricular ejection fraction; } C T R \text {, cardiothoracic ratio; } N Y H A \text {, New } \\
\text { York Heart Association (functional status); } A N P \text {, atrial natriuretic peptide; } B N P \text {, brain } \\
\text { natriuretic peptide. }\end{array}$} \\
\hline
\end{tabular}

\section{Dilated Right Ventricle and Monomorphic, Isolated Ventricular Ectopy}

Although severe, or free, PR was not observed in our study cohort, RV dilatation slowly progressed in patients with moderate or greater PR. Nonsustained, monomorphic ventricular ectopy was thought to be associated with such $\mathrm{RV}$ remodeling ${ }^{12}$; however, the relationship between nonsustained ventricular ectopy and subsequent sudden death was still questionable. ${ }^{13}$

Surgical safety and some therapeutic effects of PV replacement have been adequately discussed since the 1970s. ${ }^{14-18}$ Currently, the optimal timing of surgery is being sought because ventricular reverse remodeling has been believed to be rare when the RV volume has increased beyond a certain degree. ${ }^{19-22}$ However, the RV functional responses to surgery have not been clearly revealed. PV replacement can be done at a low risk; however, once performed, repeated valve replacement will be inevitable. Of the 73 long-term follow-up patients in the present cohort study, 71 were asymptomatic and free from any medications; thus, we hesitated to perform surgical repeat intervention, although RV dilatation was slowly progressing.

\section{Additional Perspectives for Indication of PV Annulus Preservation}

During the study period, moderate or greater PR was detected soon after regression of the RV restrictive physiology. About $50 \%$ of patients with a preoperative $\mathrm{PV}$ annulus with a $\mathrm{Z}$ value of less than -2 and/or a bicuspid PV developed moderate or greater PR within the first year after surgery. Because we had been aware of this dilemma, the indication for the preservation of the PV annulus was gradually limited to patients with a moderately small PV annulus and a tricuspid PV. Overall, $28 \%$ of this cohort had a PV annulus with a $\mathrm{Z}$ value of less than -2 .

The favorable long-term outcomes demonstrated in the present study might encourage us to reconsider the indication for the preservation of the PV annulus. A mild remaining, but insignificant, pressure gradient on the RVOT has been thought to contribute to preventing excessive RV dilatation. Nevertheless, certain patients developed significant PR in the early postoperative period. However, additional long-term follow-up is mandatory because chronic PR has been reported to cause symptoms about 30 years postoperatively.

\section{Study Limitations}

As mentioned, the indication for a strategy of preserving the PV annulus was not uniform during the study period. In addition, the PV annulus diameter itself was not the criterion used for this maneuver. For instance, a coexisting supracristal ventricular septal defect or the development of distal conus, which result in long segmental RVOT stenosis, was an indication for transannular patching if an adequate-size PV annulus was expected to be created.

The limitations of echocardiography for the estimation of RV function are well known. ${ }^{11,23}$ Cardiac magnetic resonance imaging has become the standard modality for the assessment of late RV function at our center. Although symptomatic patients who presented with significant dilatation of the right ventricle, which was assessed by echocardiography or chest radiography, subsequently underwent magnetic resonance imaging, the asymptomatic, medication-free patients still do not routinely undergo magnetic resonance imaging as a part of their annual follow-up examination. With the institution of criteria for PV replacement, the establishment of a systematic follow-up protocol will be mandatory for adult patients with congenital heart disease, because clinically sustained ventricular tachycardia and sudden death can occur long after total correction. ${ }^{12}$

Finally, the good outcomes presented are believed to have resulted, in part, from surgery without transmural ventriculotomy. However, a comparative study of patients undergoing transannular patch type repair with "minimal" 
(although the term is somewhat deceptive) right ventriculotomy or preservation of the PV annulus with separated right ventriculotomy is recommended to show the real superiority of the presented method.

\section{CONCLUSIONS}

The long-term outcomes after repair of TOF with preservation of the PV annulus were excellent. The indication for preservation of the PV annulus should be decided, not only by the PV annulus size, but also by the valvular morphology to maintain long-term PV competency. The institution of reoperation criteria for progressive $\mathrm{RV}$ dilatation resulting from coexisting PR is mandatory.

\section{References}

1. Naito Y, Fujita T, Manabe H, Kawashima Y. The criteria for reconstruction of right ventricular outflow tract in total correction of tetralogy of Fallot. J Thorac Cardiovasc Surg. 1980;80:574-81.

2. Kawashima Y, Kitamura S, Nakano S, Yagihara T. Corrective surgery for tetralogy of Fallot without or with minimal right ventriculotomy and with repair of the pulmonary valve. Circulation. 1981;64:II147-53.

3. Stellin G, Milanesi O, Rubino M, Michielon G, Bianco R, Moreolo GS, et al. Repair of tetralogy of Fallot in the first six months of life: transatrial versus transventricular approach. Ann Thorac Surg. 1995;60:588-91.

4. Rao V, Kadletz M, Hornberger LK, Freedom RM, Black MD. Preservation of the pulmonary valve complex in tetralogy of Fallot: how small is too small? Ann Thorac Surg. 2000;69:176-9.

5. Stewart RD, Backer CL, Young L, Mavroudis C. Tetralogy of Fallot: results of a pulmonary valve-sparing strategy. Ann Thorac Surg. 2005;80:1431-8.

6. Voges I, Fischer G, Scheewe J, Schumacher M, Babu-Narayan SV, Jung O, et al. Restrictive enlargement of the pulmonary annulus at surgical repair of tetralogy of Fallot: 10-year experience with a uniform surgical strategy. Eur J Cardiothorac Surg. 2008;34:1041-5.

7. Boni L, García E, Galletti L, Pérez A, Herrera D, Ramos V, et al. Current strategies in tetralogy of Fallot repair: pulmonary valve sparing and evolution of right ventricle/left ventricle pressures ratio. Eur J Cardiothorac Surg. 2009; 35:885-9.

8. Morales DL, Zafar F, Heinle JS, Ocampo EC, Kim JJ, Relyea K, et al. Right ventricular infundibulum sparing (RVIS) tetralogy of Fallot repair: a review of over 300 patients. Ann Surg. 2009;250:611-7.

9. Bacha E. Valve-sparing options in tetralogy of Fallot surgery. Semin Thorac Cardiovasc Surg Pediatr Card Surg Annu. 2012;15:24-6.

10. Sfyridis PG, Kirvassilis GV, Papagiannis JK, Avramidis DP, Ieromonachos CG, Zavaropoulos PN, et al. Preservation of right ventricular structure and function following transatrial-transpulmonary repair of tetralogy of Fallot. Eur J Cardiothorac Surg. 2013;43:336-42.

11. Rudski LG, Lai WW, Afilalo J, Hua L, Handschumacher MD, Chandrasekaran K, et al. Guidelines for the echocardiographic assessment of the right heart in adults: a report from the American Society of Echocardiography endorsed by the European Association of Echocardiography, a registered branch of the European Society of Cardiology, and the Canadian Society of Echocardiography. J Am Soc Echocardiogr. 2010;23:685-713.

12. Gatzoulis MA, Balaji S, Webber SA, Siu SC, Hokanson JS, Poile C, et al. Risk factors for arrhythmia and sudden cardiac death late after repair of tetralogy of Fallot: a multicentre study. Lancet. 2000;356:975-81.

13. Cullen S, Celermajer DS, Franklin RC, Hallidie-Smith KA, Deanfield JE. Prognostic significance of ventricular arrhythmia after repair of tetralogy of Fallot: a 12-year prospective study. J Am Coll Cardiol. 1994;23:1151-5.

14. Miller DC, Rossiter SJ, Stinson EB, Oyer PE, Reitz BA, Shumway NE. Late right heart reconstruction following repair of tetralogy of Fallot. Ann Thorac Surg. 1979;28:239-51.

15. Uretzky G, Puga FJ, Danielson GK, Hagler DJ, McGoon DC. Reoperation after correction of tetralogy of Fallot. Circulation. 1982;66:I202-8.

16. Misbach GA, Turley K, Ebert PA. Pulmonary valve replacement for regurgitation after repair of tetralogy of Fallot. Ann Thorac Surg. 1983;36:684-91.

17. Bove EL, Kavey RE, Byrum CJ, Sondheimer HM, Blackman MS, Thomas FD. Improved right ventricular function following late pulmonary valve replacement for residual pulmonary insufficiency or stenosis. J Thorac Cardiovasc Surg. 1985;90:50-5.

18. Discigil B, Dearani JA, Puga FJ, Schaff HV, Hagler DJ, Warnes CA, et al. Late pulmonary valve replacement after repair of tetralogy of Fallot. J Thorac Cardiovasc Surg. 2001;121:344-51.

19. Therrien J, Siu SC, McLaughlin PR, Liu PP, Williams WG, Webb GD. Pulmonary valve replacement in adults late after repair of tetralogy of Fallot: are we operating too late? J Am Coll Cardiol. 2000;36:1670-5.

20. Therrien J, Provost Y, Merchant N, Williams W, Colman J, Webb G. Optimal timing for pulmonary valve replacement in adults after tetralogy of Fallot repair. Am J Cardiol. 2005;95:779-82.

21. Chen PC, Sager MS, Zurakowski D, Pigula FA, Baird CW, Mayer JE Jr, et al. Younger age and valve oversizing are predictors of structural valve deterioration after pulmonary valve replacement in patients with tetralogy of Fallot. J Thorac Cardiovasc Surg. 2012;143:352-60.

22. McKenzie ED, Khan MS, Dietzman TW, Guzmán-Pruneda FA, Samayoa AX, Liou A, et al. Surgical pulmonary valve replacement: a benchmark for outcomes comparisons. J Thorac Cardiovasc Surg. February 26, 2014 [Epub ahead of print].

23. Lai WW, Gauvreau K, Rivera ES, Saleeb S, Powell AJ, Geva T. Accuracy of guideline recommendations for two-dimensional quantification of the right ventricle by echocardiography. Int J Cardiovasc Imaging. 2008;24:691-8.

\section{Discussion}

Dr Giovanni Stellin (Padova, Italy). Dr Hoashi, I enjoyed your presentation.

You are starting the long-term follow-up with a population of 84 patients from 226 who had undergone TOF repair at a single institution from 1989 to 2000 . The age of the patients at repair was quite high; as a matter of fact, the mean age was about 2 years. Also, the lower pulmonary valve $Z$ score was as low as -4.9 . However, the mean $\mathrm{Z}$ score of the $\mathrm{PV}$ for the whole population was $-1.3 ; 88 \%$ of this population underwent concomitant commissurotomy of the PV, which was stenotic. There was no mortality, with excellent survival. However, 9 patients have been lost to follow-up, making your follow-up data only $89 \%$ complete. You only had 3 reoperations, and you concluded that a bicuspid PV and $\mathrm{Z}$ score of less than -2 are risk factors for the development of $\mathrm{PR}$ in the long term.

My question is how many of these patients in this population had a hypoplastic infundibulum, which is quite common in the Oriental population, where your stenosis is limited to the very latest part of the RVOT?

Dr Hoashi. I do not remember the exact number; however, the patients who needed a shunt before the cardiac repair had severe infundibular stenosis and had mild pulmonary valvular stenosis. Also, in the early operative period, we performed the operation in patients $<6$ months old. At that time, patients who developed an anoxic spell underwent the surgery at that point. They also had severe infundibular stenosis and mild pulmonary valvular stenosis. Thus, perhaps, the total proportion of such patients was $10 \%$ to $15 \%$ of the whole study cohort.

Dr Stellin. My second question is 1 of the patients had a $\mathrm{Z}$ score, as I said before, as low as -4.9 , indicating a very hypoplastic PV annulus. I wonder, how was the pulmonary $\mathrm{RV} / \mathrm{LV}$ ratio at the end of the operation and without, I believe, any dilatation of the PV annulus? Because you did not include in your techniques any dilatation techniques but just a commissurotomy.

Dr Hoashi. Usually, we detach all the commissures from the pulmonary artery wall and separate it. After that, we measure 
the PV annular size using a bougie, and do it again and again with a gradually larger one. We do not routinely perform annulus dilatation with a balloon catheter, but such a maneuver could play the same role as balloon dilatation.

Dr Stellin. The third question: in the latest period, there is not a trend toward saving the $\mathrm{PV}$, the native $\mathrm{PV}$, and why is this? Can you explain why is that? Also, have you compared this population of patients in whom the PV was saved with those who underwent translaminar patch repair in terms of the incidence of arrhythmia, RV dilatation, and symptoms.

Dr Hoashi. At this time, we have not compared the patients who received the translaminar patch-type repair with those who underwent PV annulus preservation; thus, I cannot answer your third question.

However, for the second question, the excessive annular dilatation that resulted from detaching the PV leaflet from the annulus and sometimes dividing the PV annulus itself and/or a subclinical, but aneurysmally dilated, RVOT resulting from aggressive undermining of the RV anterior free wall muscle and resection of the subvalvular fibrous endocardium, provided sufficient relief of RVOT obstruction. However, it might have been the cause of significant PR just after surgery in the patient with a small PV annulus. We were aware of this during the study period and shifted the criteria for preservation of the PV annulus to the patients with a mildly small PV annulus.

Dr Rodolfo A. Neirotti (Cambridge, Mass). I think your effort to preserve the PV is a good idea. However, you have, in your experience, a significant incidence of arrhythmias and a significant number of patients with a dilated right ventricle.

So I have 2 questions. One is what was your incidence of right bundle block after surgery? The reason for this is that many years ago in a large series of TOF and ventricular septal defect operations, we found that the incidence of right bundle block was greater when we approached and closed the ventricular septal defect through the atrium. So, it could be important to know that.

Second, do you have any information other than the echocardiographic study about the RV function and the degree of dilatation and the RV volume?
Dr Hoashi. For your first question, the incidence of right bundle branch block?

Dr Neirotti. Yes, the incidence of right bundle block in your series. Because most of these cases were done to the right atrium, and you have your high incidence of arrhythmia. If you have that information.

Dr Hoashi. Unfortunately, I do not have the exact data now.

Dr Neirotti. Then, what about some methods other than echocardiography to evaluate the RV function and RV volume in your patients. Because you have, even with your effort of preserving the $\mathrm{PV}$, you have a significant number of patients with RV dilatation.

Dr Hoashi. So, you mean the echocardiographic evaluation of the RV function?

Dr Neirotti. That is what you have. But my question is, in addition to echocardiography, did you have other methods such as magnetic resonance imaging (MRI)?

Dr Hoashi. I see. As I presented in my slide, the limitation of echocardiography for evaluating RV function is well known. Thus, cardiac MRI has now become a standard modality in our center. However, first, we assess the RV volume using echocardiography comprehensively. Then, for patients with moderate to severe RV dilatation, we perform cardiac MRI to obtain more detailed information.

Dr Neirotti. The reason I am asking you this is because with more accurate methods of evaluating the RV function and volume, your numbers at preoperation might be much higher than the ones you have reported.

Dr Hoashi. So, the criteria for late PV replacement is still not clear. As I showed you, 71 of 74 patients are now free from medication. We hesitated to perform the reoperation for such patients. However, if the RV dilatation progressed, as I told you, we would perform MRI, and some patients might undergo redo RVOT repair in the near future.

Dr Christopher A. Caldarone (Toronto, Ontario, Canada). Did you ever use an infundibular patch in your series? I might have missed that. Meaning a patch in the infundibulum without crossing the pulmonary annulus.

Dr Hoashi. No. We perform the operation without right ventriculotomy so we do not place an incision in the right ventricle. 